\title{
DESULFURIZATION AND DEMINERALIZATION OF ASPHALTITE BY AQUEOUS CAUSTIC LEACHING
}

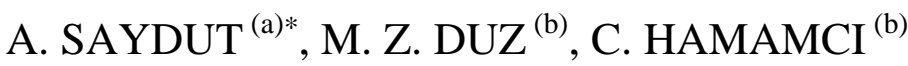 \\ (a) Department of Mining Engineering \\ Faculty of Engineering and Architecture, Dicle University, \\ TR-21280 Diyarbakir, TURKEY \\ (b) Department of Chemistry \\ Faculty of Science and Art, Dicle University \\ TR-21280 Diyarbakir, TURKEY
}

\begin{abstract}
The method of desulfurization and demineralization by aqueous caustic leaching (ACL) was used for treatment of asphaltite samples from Seguruk collieries of Sirnak asphaltite fields, situated in Southeast Anatolia region of Turkey. The effect of different parameters such as alkali concentration, time and temperature on leaching efficiency was studied, and the experimental results are presented here. The concentration of caustic was varied from 0.1 to $1.0 \mathrm{M}$, temperature from 100 to $180{ }^{\circ} \mathrm{C}$, and leaching time from 4 to $16 \mathrm{~h}$. Elevation of alkali concentration, leaching temperature and prolongation of time increase the removal of total sulfur and ash. As a result of ACL, ash content of asphaltite was reduced from 40.08 to $22.14 \%$, and $75 \%$ of combustible was recovered. Total sulfur and volatile matter content was reduced from 6.74 to $2.49 \%$ and from 33.72 to $19.10 \%$, respectively.
\end{abstract}

\section{Introduction}

According to the World Energy Council and Turkish National Committee (1998), the total reserve of asphaltic substances which are found in southeastern Turkey is about 82 million tonnes, with Silopi and Sirnak reserves together comprising the major part of the asphaltite deposits. Sirnak deposits have been described as asphaltic pyrobitumen associated with mineral matter. Asphaltic substances are generally believed to be formed by migration of petroleum followed by alteration during burial. Eventhough asphaltites have the physical appearance of coal, they are derived from crude oil which migrated to inorganic formations. By the effect of catalytic activity of inorganic matrix, metamorphosis has taken place to produce condensed

*Corresponding author: e-mail saydut@dicle.edu.tr 
heavier hydrocarbon structures due to various chemical, physical, and biological changes [1-8].

Although asphaltite is being utilized as an alternative to coal for domestic heating, the difference in the oxygen content of coal (2-23\%) and asphaltite, which involves oxygen or oxygen compounds in very little amounts, is one of the important facts showing its petroleum origin. Despite several ways and alternatives for asphaltite utilization, it has been widely used as a supplement to lignite for domestic heating in the Southeast Anatolia of Turkey since the 1970s [5]. On the other hand, asphaltites could be used as fuel in thermal power stations for electricity production. Some valuable elements may be recovered from their ashes [9-10]. However, because of high amounts of sulfur, volatile compounds and ashes, processing of asphaltites causes environmental, industrial and technological problems. Combustion of high-sulfur fossil fuel produces $\mathrm{SO}_{2}$ which is corrosive and toxic. Sulfur dioxide is subsequently converted to $\mathrm{SO}_{3}$, which in contact with water forms sulfuric acid. $\mathrm{SO}_{3}$ leads to formation of acid rain and corrosion of boilers, underground pipelines, metallic installations, mine machinery, etc. Ash lowers the combustion efficiency of boilers and causes other deleterious effect. Ash handling and disposal of ash are also problems. Therefore, it is necessary to remove the mineral matter and sulfur from coal and asphaltite prior to its utilization.

Demineralization and desulphurization of southeast Anatolia asphaltites has been achieved by physical methods. The physical methods are based on differences in the physical properties of the minerals and carbonaceous part of the asphaltite. Chemical methods are also effective for removing mineral matters which are finely distributed and bound strongly to the solid fossil fuels. Most of the pyritic and sulfate sulfur in Sirnak asphaltites was eliminated using the Meyers method [11]. Besides this method, chemical cleaning of solid fuel and oil asphaltene has been studied using alkali solutions [12-23]. During the aqueous caustic leaching of solid fuel, caustic reacts with minerals and organo sulfur compounds present in fuel to form water-soluble alkali metal salts [24]. Caustic is consumed during aqueous caustic leaching by reactions leading to the removal of ash and pyrite as well as by reactions leading to the removal of organic sulfur. Reactions typical of those leading to the removal of inorganic components from fuel during aqueous caustic leaching occur according to Equations 1 and 2.

$$
\begin{gathered}
\mathrm{SiO}_{2}+2 \mathrm{NaOH} \rightarrow \mathrm{Na}_{2} \mathrm{SiO}_{3}+\mathrm{H}_{2} \mathrm{O} \\
4 \mathrm{FeS}_{2}+20 \mathrm{NaOH} \rightarrow 4 \mathrm{NaFeO}_{2}+8 \mathrm{Na}_{2} \mathrm{~S}+10 \mathrm{H}_{2} \mathrm{O}+\mathrm{O}_{2}
\end{gathered}
$$

Since these products are soluble in the extraction solution, they can be removed from the fuel. The spent alkali can be regenerated and recycled to the process [22].

Reserves of asphaltites are of particular interest because the feed asphaltites are rich in organic sulfur. The objective of our work was to evaluate the effect of aqueous caustic leaching on desulfurization and 
deashing of asphaltite rich in organic sulfur and to study the effects of varying several experimental parameters on the efficiency of sulfur and ash removal.

\section{Experimental}

Asphaltite samples were collected from Seguruk reserves from Sirnak in SE Anatolia of Turkey. The samples were stored under atmospheric conditions and ground to below $0.071 \mathrm{~mm}$ fineness and preserved in an airtight container.

Heating value, ash content, and sulfur distribution of the raw and treated asphaltites were determined according to ASTM procedures. Elemental analysis $(\mathrm{C}, \mathrm{H}, \mathrm{N})$ of the asphaltite samples was performed by a Carlo Erba elemental analyzer EA 1108. Elemental composition for chemical characterization of the samples was determined according to standard methods (ASTM D 1103-80). Table 1 presents the data on proximate and elemental analyses and sulfur distribution of the studied asphaltite. Reagent-grade sodium hydroxide was used without further purification.

Ten grams of the asphaltite sample were mixed by continuous shaking with $100 \mathrm{ml}$ sodium hydroxide solution of different concentration $(0.1,0.5$ and $1.0 \mathrm{M}$ ) in a bath, varying reaction temperature from 100 to $180{ }^{\circ} \mathrm{C}$ and reaction time from 4 to $16 \mathrm{~h}$. After completion of leaching, the product (improved asphaltite) was filtered and washed with distilled water and dried for the analysis of ash and sulfur.

Table 1. Sulfur distribution, elemental and proximate analysis of Segürük asphaltites, wt.\%

\begin{tabular}{|l|r|l|l|l|r|}
\hline \multicolumn{2}{|c|}{ Proximate analysis } & \multicolumn{2}{c|}{ Sulfur distribution } & \multicolumn{2}{c|}{ Elemental analysis } \\
\hline Moisture & 0.62 & Total sulfur & 6.74 & Carbon & 46.77 \\
Ash & 40.80 & Pyritic sulfur & 2.35 & Nitrogen & 0.76 \\
Fixed carbon & 24.86 & Sulphate sulfur & 0.32 & Hydrogen & 4.40 \\
Volatile matter & 33.72 & Organic sulfur & 4.07 & & \\
\hline Heating value, $\mathrm{kcal} \mathrm{g}^{-1}$ & 5430 & \multicolumn{4}{|l}{} \\
\hline
\end{tabular}

\section{Results and discussion}

The effect of leaching the asphaltite samples with aqueous caustic on the removal of pyritic and organic sulfur, ash and volatile matter was discussed considering $\mathrm{NaOH}$ concentration, leaching time and temperature. Reduction of ash ranges from 11 to $45 \%$, that of total sulfur from 16 to $63 \%$, pyritic sulfur from 21 to $85 \%$, organic sulfur from 7 to $51 \%$ and volatile matter from 8 to $43 \%$, depending on experimental conditions. 
$\mathrm{NaOH}$ was used to evaluate whether alkali would enhance the desulfurization and demineralization efficiency. Under reduction conditions, C-S bond might be cleaved easily by the attack of base. The effect of alkali concentration on desulfurization and demineralization of Seguruk asphaltite is illustrated by data in Table 2 . One can see that the increase in alkali concentration from 0.1 to $1.0 \mathrm{M}$ at $100{ }^{\circ} \mathrm{C}$ at treatment for $8 \mathrm{~h}$ increases sulfur and ash removal from the asphaltite sample. The percentage of pyritic sulfur removal was higher than that of organic sulfur. The removal of ash was around $25 \%$ at the highest concentration of alkali. Ash reduction was gradually decreased by increasing alkali concentration. The content of solid matter in asphaltite was decreased by increasing alkali concentration, and $87 \%$ of Seguruk asphaltite remained unchanged.

Table 2. Effect of amount of aqueous caustic on removal of sulfur and ash from Segürük asphaltite leached for $8 \mathrm{~h}$ at $100{ }^{\circ} \mathrm{C}$

\begin{tabular}{|c|c|c|c|c|c|c|c|c|c|c|c|}
\hline \multirow[b]{2}{*}{$\mathrm{NaOH}, \mathrm{M}$} & \multicolumn{2}{|c|}{ Pyritic S, \% } & \multicolumn{2}{|c|}{ Organic S, \% } & \multicolumn{2}{|c|}{ Total S, \% } & \multicolumn{2}{|c|}{ Ash, $\%$} & \multicolumn{2}{|c|}{$\begin{array}{l}\text { Volatile } \\
\text { matter, \% }\end{array}$} & \multirow{2}{*}{ 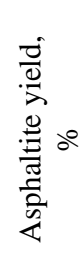 } \\
\hline & $\stackrel{0}{0}$ & 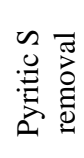 & $\begin{array}{l}n \\
.0 \\
\tilde{\Xi} \\
0 \\
0 \\
0\end{array}$ & 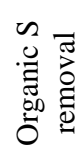 & $\begin{array}{l}n \\
\stackrel{\pi}{0} \\
0\end{array}$ & 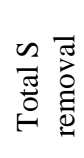 & $\frac{\tilde{5}}{4}$ & 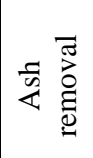 & $\begin{array}{l}\bar{\Xi} \\
\stackrel{ \pm}{ \pm} \\
\Xi \\
\dot{0} \\
\dot{0}\end{array}$ & 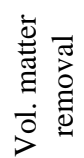 & \\
\hline $\begin{array}{l}\text { Without } \\
\text { treatment }\end{array}$ & 2.35 & - & 4.08 & - & 6.74 & - & 40.08 & - & 33.72 & - & 100 \\
\hline $0.1 \mathrm{M}$ & 1.86 & 20.85 & 3.80 & 6.86 & 5.65 & 16.17 & 35.78 & 10.72 & 30.96 & 8.19 & 94.87 \\
\hline $0.5 \mathrm{M}$ & 1.40 & 40.43 & 3.48 & 14.70 & 4.87 & 27.74 & 34.00 & 15.17 & 28.00 & 16.96 & 88.45 \\
\hline $1.0 \mathrm{M}$ & 0.94 & 60.00 & 3.44 & 15.69 & 4.37 & 35.16 & 30.75 & 23.28 & 26.85 & 20.37 & 86.50 \\
\hline
\end{tabular}

To control the effect of leaching time on desulfurization and removal of ash from asphaltite samples, $1.0 \mathrm{M}$ was chosen for alkali concentration because at this concentration sulfur removal was highest. Leaching temperature for that parameter was taken again $100{ }^{\circ} \mathrm{C}$, and the results obtained are given in Table 3 . The increase in contact time with alkali affects desulfurization positively. The increase in percentage of ash removal from both asphaltites was the same. The yield of asphaltites was decreased by $4 \%$.

The effect of leaching temperature on demineralization and desulfurization of asphaltites is presented in Table 4. At $180{ }^{\circ} \mathrm{C}$ the percentage of pyritic sulfur removal was 85 , and the level of organic sulfur was decreased up to $51 \%$. The increase of temperature from 100 to $180{ }^{\circ} \mathrm{C}$ increased the removal of ash from 30 to $45 \%$. The content of solid matter in Seguruk and Halbur asphaltites was $75 \%$. The changes in the amount of volatile matter were also controlled by alkali concentration, leaching time and temperature. An increase in every parameter decreased the amount of the volatile matter, the overall decrease in volatile matter being $43 \%$ for Seguruk asphaltite. 
Table 3. Effect of time on removal of sulfur and ash from Segürük asphaltite leached with $\mathrm{NaOH}(1.0 \mathrm{M})$ at $100{ }^{\circ} \mathrm{C}$

\begin{tabular}{|c|c|c|c|c|c|c|c|c|c|c|c|}
\hline \multirow[b]{2}{*}{ Time, $\mathrm{h}$} & \multicolumn{2}{|c|}{ Pyritic S, \% } & \multicolumn{2}{|c|}{ Organic S, \% } & \multicolumn{2}{|c|}{ Total S, \% } & \multicolumn{2}{|c|}{ Ash, $\%$} & \multicolumn{2}{|c|}{$\begin{array}{c}\text { Volatile matter, } \\
\%\end{array}$} & \multirow{2}{*}{ 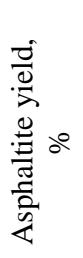 } \\
\hline & : & 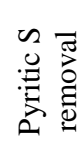 & $\begin{array}{l}n \\
.0 \\
\vdots \\
0 \\
0 \\
0\end{array}$ & 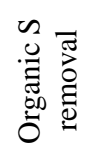 & $\begin{array}{l}n \\
\frac{\pi}{0} \\
\stackrel{0}{0}\end{array}$ & 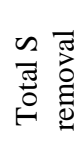 & $\frac{\pi}{4}$ & 蛋总 & 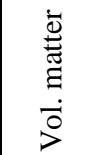 & 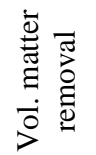 & \\
\hline $\begin{array}{l}\text { Without } \\
\text { treatment }\end{array}$ & 2.35 & - & 4.08 & - & 6.74 & - & 40.08 & - & 33.72 & - & 100 \\
\hline $4 \mathrm{l}$ & 1.88 & 20.00 & 3.80 & 6.86 & 5.67 & 15.88 & 36.00 & 10.18 & 30.30 & 10.14 & 94.06 \\
\hline $8 \mathrm{l}$ & 0.94 & 60.00 & 3.44 & 15.69 & 4.37 & 35.16 & 30.75 & 23.28 & 26.85 & 20.37 & 86.50 \\
\hline $16 \mathrm{~h}$ & 0.70 & 70.21 & 3.20 & 21.57 & 3.89 & 42.28 & 28.00 & 30.14 & 23.02 & 31.73 & 82.54 \\
\hline
\end{tabular}

Table 4. Effect of temperature on removal of sulfur and ash from Segürük asphaltite leached with $\mathrm{NaOH}(1.0 \mathrm{M})$ for $16 \mathrm{~h}$

\begin{tabular}{|c|c|c|c|c|c|c|c|c|c|c|c|}
\hline \multirow[b]{2}{*}{$\begin{array}{l}\text { Tempera- } \\
\text { ture, }{ }^{\circ} \mathrm{C}\end{array}$} & \multicolumn{2}{|c|}{ Pyritic S, \% } & \multicolumn{2}{|c|}{ Organic S, \% } & \multicolumn{2}{|c|}{ Total S, \% } & \multicolumn{2}{|c|}{ Ash, $\%$} & \multicolumn{2}{|c|}{$\begin{array}{l}\text { Volatile matter, } \\
\%\end{array}$} & \multirow{2}{*}{ 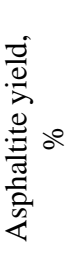 } \\
\hline & 怘 & 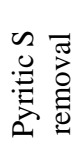 & 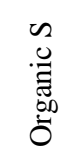 & 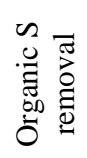 & 吾舟 & $\begin{array}{ll}\sim & \pi \\
\pi & 0 \\
0 & 0 \\
0 & 0\end{array}$ & $\frac{\pi}{\frac{\pi}{4}}$ & 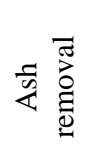 & 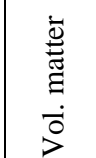 & 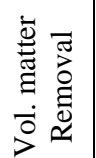 & \\
\hline $\begin{array}{l}\text { Without } \\
\text { treatment }\end{array}$ & 2.35 & - & 4.08 & - & 6.74 & - & 40.08 & - & 33.72 & - & 100 \\
\hline $100^{\circ} \mathrm{C}$ & 0.70 & 70.21 & 3.20 & 21.57 & 3.89 & 42.28 & 28.00 & 30.14 & 23.02 & 31.73 & 82.54 \\
\hline $140^{\circ} \mathrm{C}$ & 0.50 & 78.72 & 2.83 & 30.64 & 3.41 & 49.41 & 25.05 & 37.50 & 22.06 & 34.60 & 78.55 \\
\hline $180^{\circ} \mathrm{C}$ & 0.35 & 85.10 & 2.00 & 50.98 & 2.49 & 63.06 & 22.14 & 44.76 & 19.10 & 43.36 & 74.86 \\
\hline
\end{tabular}

The presence of alkali brings about pyrolysis and subsequent depolymerization of asphaltite and thus about the increase in sulfur removal. This is attributed to solubilization of sulfates, conversion of pyritic and some organic functional groups like thiols, disulfide, etc., present in asphaltites to soluble salts after leaching with $\mathrm{NaOH}$. Strong alkali probably removes aliphatic sulfur and some simple heterocyclic compounds present in the asphaltite samples. With repetition of the process, the content of organic sulfur decreases as a result of breaking up of some C-S bonds, which sometimes leads to elimination of sulfur from coal and asphaltites. Sulfur occurs in all samples studied in organic compounds. Results of this study show that chemical cleaning by leaching with aqueous caustic, followed by water washes, can effectively remove much of organic sulfur from asphaltites rich in organic sulfur. 
It is possible to remove $85 \%$ of pyritic sulfur, $51 \%$ organic sulfur, $45 \%$ of ash and $43 \%$ of volatile matter from asphaltites by leaching with $1 \mathrm{M}$ alkali at $180{ }^{\circ} \mathrm{C}$ for $16 \mathrm{~h}$. However, successful removal of pyritic and organic sulfur and ash causes a decrease in the solid matter content of the yielded product. The effectiveness of the process depends on the amount of different forms of sulfur in fuels of different nature and composition.

\section{Conclusions}

- The effect of aqueous caustic leaching of asphaltite from Seguruk (Sirnak, SE Anatolia, Turkey) with aqueous sodium hydroxide on demineralization and desulfurization was investigated.

- Most of inorganic sulfur and a significant portion of organic sulfur were removed.

- ACL of asphaltite samples gave optimum results at $180^{\circ} \mathrm{C}$, with $1 \mathrm{M} \mathrm{NaOH}$ and $16 \mathrm{~h}$ leaching time.

- ACL reduced ash content of Seguruk (Sirnak) asphaltite by $44.76 \%$, pyritic sulfur, $85.10 \%$, organic sulfur $50.98 \%$, total sulfur $63.06 \%$; and volatile matter content by $43.36 \%$. The asphaltite yield was $74.86 \%$.

\section{REFERENCES}

1. Gonenc, $O$. Asphaltites and asphaltite deposits of Turkey // A report of M.T.A. 1990 [in Turkish].

2. Hamamci, C., Duz, M. Z., Saydut, A., Merdivan, M. Elemental composition of Southeastern Anatolia asphaltites (Turkey) as a function of particle size // Oil Shale. 2003. Vol. 20, No. 2. P. 161-166.

3. Orhun, F. The Characteristics, Metamorphism Degrees and Classification Problems of Asphaltic Materials in Southeastern Turkey // M.T.A 1969. J 72. P. 146-157.

4. Akrami, H. A. E., Yardim, M. F., Ekinci, E. Preparation of stabilized fiber from Avgamasya asphaltite // Energy \& Fuels. 1999. Vol. 13, No. 5. P. 1030-1036.

5. Altun, N. E., Kök, M. V., Hicyilmaz, C. Effect of particle size and heating rate on the combustion of Silopi asphaltite // Energy \& Fuels. 2002. Vol.16, No. 3. P. 785-790.

6. Altun, N. E., Hicyilmaz, C., Kök, M. V. Effect of particle size and heating rate on the pyrolysis of Silopi asphaltite // J. Anal. Appl. Pyrol. 2003. Vol. 67, No. 2. P. 369-379.

7. Ballice, L. Oxidation studies on Sirnak asphaltites. Determination of kinetic parameters // Oil Shale. 2004. Vol. 21, No. 3. P. 217-225.

8. Tonbul, Y., Saydut, A., Hamamci, C. Pyrolysis kinetics of asphaltites determined by thermal analysis // Oil Shale. 2006. Vol. 23, No. 3. P. 286-293.

9. Baysal, A., Akba, O., Merdivan, M., Hamamci, C., Gumgum, B. Comparison of microwave digestion procedures for the determination of some elements in 
asphaltite ash using ICP-AES // Annali Di Chimica. 2002. Vol.92, No. 11-12. P. 1127-1133.

10. Karayigit, A. I., Querol, X. Minerology and elemental contents of the Sirnak asphaltite, Southeast Turkey // Energy Sources. 2002. Vol. 24, No. 8. P. 703713.

11. Hamamci, C., Kahraman, F., Duz, M.Z. Desulfurization of southeastern Anatolian asphaltites by the Meyers method // Fuel Process. Technol.1997. Vol. 50, No. 2-3. P. 171-177.

12. Balaz, P., LaCount, R. B., Kern, D. B., Turcaniova, L. Chemical treatment of coal by grinding and aqueous caustic leaching // Fuel. 2001. Vol. 80, No. 5. P. 665-671.

13. Mukherjee, S., Borthakur, P. C. Effect of leaching high sulfur subbituminous coal by potassium hydroxide and acid on removal of mineral matter and sulphur // Fuel. 2003. Vol. 82, No. 7. P. 783-788.

14. Mukherjee, $S$. Demineralization and desulfurization of high-sulfur Assam coal with alkali treatment // Energy \& Fuels. 2003. Vol. 17, No. 3. P. 559-564.

15. Mukherjee, S., Borthakur, P. C. Effects of alkali treatment on ash and sulfur removal from Assam coal // Fuel Process. Technol. 2003. Vol. 85, No. 2-3. P. 93-101.

16. Kara, H., Ceylan, $R$. Removal of sulphur from four Central Anatolian lignites by $\mathrm{NaOH} / /$ Fuel. 1988. Vol. 67, No. 2. P. 170-172.

17. Lee, S. H., Choi, C. S. Chemical activation of high sulfur petroleum cokes by alkali metal compounds // Fuel Process. Technol. 2000. Vol. 64, No. 1-3. P. 141-153.

18. Karacan, O., Kök, M. V., Karaaslan, $U$. Changes in thermal properties of crude oil asphaltenes induced by $\mathrm{NaOH}$ treatment// Fuel Process. Technol. 1999. Vol. 59, No. 1. P. 13-21.

19. Saydut, A., Tonbul, Y., Baysal, A., Duz, M. Z., Hamamci, C. Froth flotation pretreatment for enhancing desulfurization of coal with sodium hydroxide // J. Sci. Ind. Res. 2007. Vol. 66, No. 1. P. 72-74.

20. Hicyilmaz, C., Altun, N. E. Demineralization of Sirnak asphaltites by flotation // Oil Shale. 2006. Vol. 23, No. 2. P. 144-159.

21. Bolat, E., Saglam, S., Piskin, S. Chemical demineralization of a Turkish high ash bituminous coal // Fuel Process. Technol. 1998. Vol. 57, No. 2. P. 93-99.

22. Yaman, S., Kucukbayrak, S. Sulfur removal from Gediz lignite using aqueous sodium hydroxide solutions under mild oxidative conditions // Energy Sources. 1999. Vol. 21, No. 9. P. 829-837.

23. Chriswell, C. D., Markuszewski, R., Jewell, D. V. Improved caustic coal desulfurization by a float-sink/leaching process employing $50 \%$ aqueous $\mathrm{NaOH}$ solutions // Fuel Process. Technol. 1994. Vol. 37, No. 1. P. 19-32.

24. Ityokumbul, M. T. Experimental evaluation of molten caustic leaching of an oil sand coke residue // Canadian J. Chem. Eng. 1994. Vol. 72, No. 2. P. 370-374.

Presented by A. Lapidus

Received March 9, 2007 